\title{
Empirical research on the functions of audiovisual advertising from the perspective of recipients - students of the Journalism and Social Communication Faculty at the University of tódź
}

\author{
Agnieszka Barczyk-Sitkowska \\ ORCID: 0000-0002-1149-2317 \\ UNIVERSITY OF tÓDŹ, POLAND \\ Mateusz Krzekotowski \\ ORCID: 0000-0002-7113-0078 \\ UNIVERSITY OF tÓDŹ, POLAND
}

DOI: 10.19195/1899-5101.12.1(22).3

\begin{abstract}
In current research on the subject, three dominant functions of advertising can be pointed out. These are: to inform, to persuade or to remind a recipient about the product. However, watching modern commercials in the media evokes a question about this typology being sufficient enough to cover the full spectrum of the commercial industry. The main goal of the article is to test the attitudes towards commercials in students in their junior year of the Journalism and Social Communication degree at the University of Łódź. This probe is exceptionally valuable, since many of these people in years to come will become involved in creating this type of broadcast by graduating with a "Advertising, Design and Visual Communication" major at our university. The experiment has been divided into three tiers, showing different types of TV spots in two of them. Doing this has enabled us to answer the question if watching these types of broadcasts can influence the attitude towards commercials and its functions on viewers.
\end{abstract}

KEYWORDS: commercial, TV spot, function, advertainment.

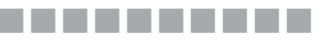

\section{INTRODUCTION}

We understand the term 'commercial' as a mass broadcast, conceived by the sender and addressed to the recipients for attaining a specific purpose. To describe the mechanism behind such a message, we can use the model of persuasive act 
proposed by Lasswell (Goban-Klas, 2004, pp. 56-57). Goban-Klas points out that "Lasswell's Model is best used in these forms of communication, that show a distinctively instrumental characteristic, which means that the sender has a clear purpose: to change the attitude or behaviour of the recipients" (Goban-Klas, 2004, p. 57). This article is connected to the last part of this model, hence the effects of the communication process. These results are what we call 'functions' - in literature, they have been described thoroughly by Oniszczuk (1988).

Typologies of advertising roles found in Polish research offer three distinctive roles of influencing the attitude of the recipients (their opinions, emotions and behaviours). These classifications draw attention to the informational function of advertising (allowing the recipients to acquaint themselves with the advertised product or service), persuasive function (encouraging consumers to buy the advertised product) and reminding function (preserving the existence of the product in consumers' minds and building their loyalty towards it). These three functions are dominant in the literature connected to economics and marketing. As an example, we recall the works of Kozłowska (2001, p. 32) or Grzegorczyk (2010, p. 43). All of these are thus connected with the presentation and exposition of the product. However, the transformation of advertising communication and the rise of advertainment forces us to pose a question about the purpose of modern advertising.

The research conducted in 2011 by CBOS shows that $86 \%$ of Poles do not like watching commercials. As a result this challenges Polish advertisers to create broadcasts that will not leave the viewers feeling bored and/or irritated. A common solution is to use the convention of entertainment, such as storytelling, which uses the broadcast merely as an excuse to advertise the product. The first worldwide example of this practice was the series The Hire (BMW, 2001-2002) (Russell, 2007, p. 6). This new approach to commercials (based on the notion that the commercial serves primarily to entertain the viewer and to build a positive brand image), forces us to enrich the catalogue of advertising roles.

In our article, we pose the question about the functions of advertising as perceived by students in their junior year of Journalism and Social Communication at the University of Łódź. In their second year, these people chose one of three majors: (1) journalism and media critique, (2) advertising, design and visual communication, (3) media research. We can presume that at least some of our students will work in the commercial industry in the future, so they will create an impact on the Polish commercial industry, creating persuasive broadcasts. In the experiment designed by us, we tried to verify if the commercials presented by us can change the attitudes of the recipients. Detailed hypothesis of our research will be presented in the part dedicated to methodology and the results of our empirical research. This part is preceded by a short theoretical summary of advertising functions, based on the works of Polish researchers. 


\section{ROLES OF ADVERTISING}

As mentioned previously, Polish researchers mention three advertising roles: to inform, persuade and remind the viewer. Kozłowska is one of the researchers providing detailed explanation of these roles. She describes the informational role of advertising as one which allows the consumer to be acquainted with specific goods: "Therefore they have the ability to identify basic specifications of the product: its physical appearance (e.g., price, size, colour) and the benefits of buying them" (Kozłowska, 2001, pp. 32-33). The second mentioned role includes all of the persuasive methods used to convince the viewer to buy the specific product or service, usually using "significant product distinction" (Kozłowska, 2001, p. 33)..$^{1}$ The presented typology is completed by a reminding role that enforces the validity of the viewer's action (so buying the product) (Kozłowska, 2001, p. 33).

However, already in 2007, Michalik pointed out that the three main roles of advertising are not sufficient for building a discourse. In his opinion, advertising communication is becoming more and more about entertaining the recipient. He writes: "It can be seen on two levels. Firstly, the entertaining value is seen in the fact that watching commercials for many people is becoming a form of entertainment. Commercials are sources of fun and aesthetical experiences, so watching them becomes more pleasurable than reading newspapers or watching other [TV] shows. The other level of entertainment can be seen in the manner of building commercial content (e.g., using humour, catchy jingles, exotic cultures or eroticism). Therefore the entertaining role must not be seen as additional, but often as primary to the three main ones" (Michalik, 2007, pp. 16-17). This point of view was the main inspiration for writing this article.

Similar, yet different roles are presented in CATI research conducted by Wszołek for his work entitled: Reklama - perspektywa empiryczna (Commercial - An empirical perspective) (2016). The focus group for his study consisted of over 500 respondents. One of the questions posed by the researcher in his questionnaire read: "In your opinion, what is the role of a commercial?" As mentioned by the author: "Based on the data, there is a possibility of pinpointing three main roles of commercials: marketing-related, manipulative and informational" (Wszołek, 2016, p. 53). The marketing and informational roles were mentioned in previously discussed works, however, this paper introduces us to a new role of commercial - the manipulative one (Wszołek, 2016, pp. 55-58).

Another approach is presented by Golka, who claims that "advertising is effective when it uses all the functionalities of language communication" (1994, p. 74). The author refers to works of Umberto Eco as his inspiration. In none of the previously mentioned research was the aesthetic function mentioned as a key element in the commercial landscape (Eco, 1996, p. 178). It seems that nowadays

\footnotetext{
${ }^{1}$ All cited fragments in the Authors' own translation.
} 
advertisers put a lot of effort for their broadcasts to become both attractive and to attract attention. As a result, we can presume that advertising might be a source of aesthetical pleasure.

\section{RESEARCH PRESENTATION}

For the purposes of this research a nine-question questionnaire has been created. Our experiment was conducted on the focus group of 60 people, divided into three tiers. All of them were students in the junior year in Journalism and Social Communication classes. Tables 1 and 2 present the division in the sex and age category.

Table 1. Sex of our respondents (in numbers)

\begin{tabular}{|c|c|c|c|c|c|}
\hline \multicolumn{6}{|c|}{ Respondents - 60 people } \\
\hline \multicolumn{3}{|c|}{ Women (W) - 36 } & \multicolumn{3}{c|}{ Men (M) - 24 } \\
\hline \multicolumn{2}{|c|}{ Tier I } & \multicolumn{2}{c|}{ Tier II } & \multicolumn{2}{c|}{ Tier III } \\
\hline W & M & W & M & W & M \\
\hline 12 & 8 & 12 & 8 & 12 & 8 \\
\hline
\end{tabular}

Source: Authors.

Table 2. Age of our respondents (in numbers)

\begin{tabular}{|c|c|c|c|c|c|}
\hline \multicolumn{6}{|c|}{ Respondents - 60 people } \\
\hline \multicolumn{3}{|c|}{ Under $18 \mathrm{y} / 0-3$} & \multicolumn{3}{|c|}{$18-29$ y/o -57} \\
\hline \multicolumn{2}{|c|}{ Tier I } & \multicolumn{2}{|c|}{ Tier II } & \multicolumn{2}{|c|}{ Tier III } \\
\hline$<18 \mathrm{y} / \mathrm{o}$ & $\begin{array}{c}18-29 \\
\text { y/o }\end{array}$ & $<18 \mathrm{y} / \mathrm{o}$ & $\begin{array}{c}18-29 \\
\text { y/o }\end{array}$ & $<18 \mathrm{y} / \mathrm{o}$ & $\begin{array}{c}18-29 \\
\text { y/o }\end{array}$ \\
\hline 1 & 19 & 2 & 18 & 0 & 20 \\
\hline
\end{tabular}

Source: Authors.

In the designed research, we used "a model with a focus group without pretest" (Olszanecka-Marmola, 2016, p. 109). As described by the author, "In this example, the difference is made post-test between the experiment group (which we impact by our variable) and our control group. The basic advantage of this scheme comes from the fact that one-time measurement allows us to obtain more accurate results, because the lack of a pre-test makes our research group numb to our actions. By this, they cannot guess the real purpose of the experiment, which makes its inner accuracy greater" (Olszanecka-Marmola, 2016, pp. 109-110). 
The task of the control group (group 1) was to complete a questionnaire. Experimental groups before giving answers watched three commercials. Group 2 had to watch three commercials deemed by our research as traditional (banking advertisement, mobile phone advertisement and auction service). The materials used in our experiment can be found on YouTube:

— https://www.youtube.com/watch?v=RfOMzaB8lLQ;

- https://www.youtube.com/watch?v=Tl38Mw5z4Xs;

- https://www.youtube.com/watch?v=8yfa7PswqO4.

The second experimental group (group 3 ) watched advertainment examples (with the same categories), then completed the questionnaire. The materials used in our experiment can be found on YouTube:

- https://www.youtube.com/watch?v=-Jb-1LgCY1M;

- https://www.youtube.com/watch?v=8TuFEqKUcd4;

- https://www.youtube.com/watch? $=$ =tU5Rnd-HM6A\&t=8s.

Every group answered the same questions connected with the perception and the functions of commercials, the irrespective variable being the broadcasts shown during the experiment and the interchangeable one the attitudes towards commercials and their functions in our viewers.

In our opinion these experiments allowed us to: (1) answer the question about the roles of contemporary advertising (from the perspective of students of journalism and social communication at our university); (2) check the relations between selected commercial functions and the type of commercials presented during the experiment (hence to verify if recently-seen broadcasts can alter the perception of commercial functions). Based on our notions, we posed the following hypotheses:

H1: Every respondent will have a negative attitude towards commercials, however, this indicator will be lower in the tier watching advertainment examples.

$\mathrm{H} 2$ : All of the respondents will feel equally forced to watch commercials.

H3: The first and second tier of our subjects will mainly point out the persuasive role of commercials (secondly informational and reminding ones). The respondents from the third tier will be keener on choosing entertaining and aesthetic roles.

H4: The notion of having a favourite commercial will be more frequent in the respondents from the third tier.

\section{VERIFYING THE HYPOTHESIS}

H1: Every respondent will have a negative attitude towards commercials, however, this indicator will be lower in the tier watching advertainment examples.

The answers given by respondents in the first question were surprising. Only $22 \%$ (or 13 people, so the smallest group of our research) declared a negative attitude towards commercials. 


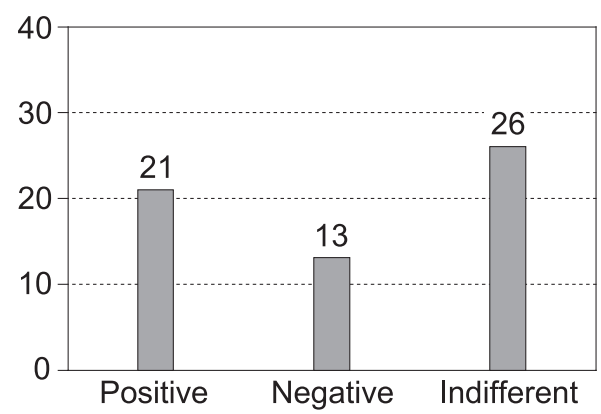

Figure 1. Attitude towards commercials (responses: 60) (in numbers)

Source: Authors.

The analysis of responses in the tiers verifies the first hypothesis. Contrary to our belief - a negative attitude is not dominant. The responses of participants who did not view any commercials prior to taking part in the experiment formed evenly in the ratio: 7 (positive) -6 (negative) -7 (indifferent). What is interesting, however, is that the negative attitude towards commercials was the least recorded one. What is more surprising, is that the results seen in the second tier (standard commercials) show the dominance of indifferent attitudes towards commercials. Perhaps the recipients who were forced to watch another bunch of generic commercials, similar to the ones shown on TV every day were indifferent to this form of broadcast. According to our expectations, the least negative attitude towards commercials was observed in the third tier, at the same time $50 \%$ of respondents declared a positive attitude towards commercials. This can be explained by the so-called freshness effect - respondents were judging commercials on the basis of their recent exposure to them (Aronson et al., 1997, p. 139). The participants judged the commercials by the most recent broadcasts they watched.

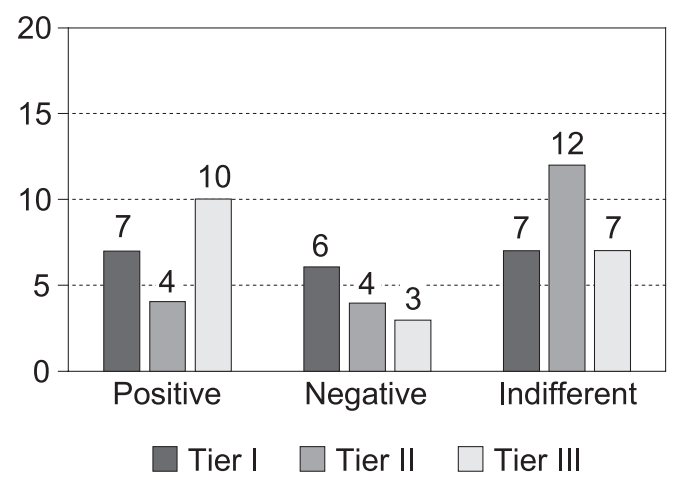

Figure 2. Attitude towards commercials in tiers (in numbers)

Source: Authors. 


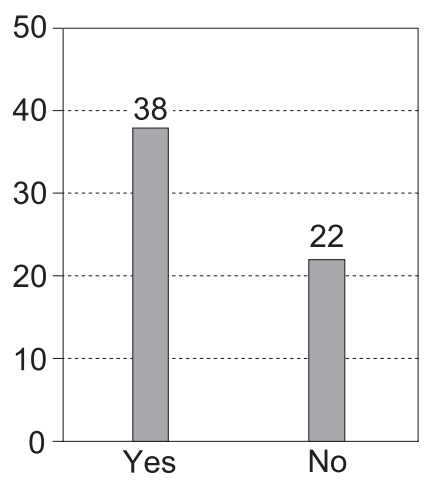

Figure 3. The impression of being forced to watch commercials (Respondents:

60) (in numbers)

Source: Authors.

$\mathrm{H}$ 2: All of the respondents will feel equally forced to watch commercials.

The results confirm this tendency -38 out of 60 people (63\%) felt that way. However, as many as 22 people (37\%) did not share that impression. Eight of them declared positive, and twelve indifferent attitudes towards commercials.

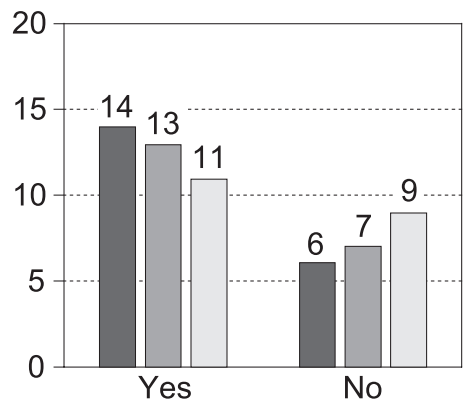

Tier I $\square$ Tier II $\square$ Tier III

Figure 4 . The feeling of restraint from watching commercials (in numbers)

Source: Authors.

Interestingly, the division of answers within the tiers shows that people who did not see any of the commercials presented by us felt the biggest restraint from watching them. The lowest number of positive responses to this question was shown in the last group, most favourable towards commercials.

Respondents were free to input their own answer in the question about the motivation behind watching commercials. This kind of question proves to be beneficial, allowing us to fully get into the mindset of our participants, however, it makes organising our research much harder. Basic analysis of all these answers allowed us to divide them into a few themes. These along with sample answers are presented in Table 3. 
Table 3. Motivation behind watching commercials

\begin{tabular}{|c|c|c|c|}
\hline Tier & Answer type & $\begin{array}{l}\text { Number } \\
\text { of picks }\end{array}$ & Examples \\
\hline \multirow{7}{*}{ I } & No answer & 1 & - \\
\hline & Not watching & 2 & "I don't watch commercials" \\
\hline & I don't know & 0 & - \\
\hline & No choice & 8 & $\begin{array}{l}\text { "because they play automatically", "I have no choice", } \\
\text { "I have to", "some cannot be omitted", "they are forced } \\
\text { upon", "because I'm waiting for the second part of the } \\
\text { movie" }\end{array}$ \\
\hline & Self-chosen & 6 & $\begin{array}{l}\text { "I’m interested in them", "it's educational - graphics/ } \\
\text { idea", "for aesthetical reasons", "to draw inspiration", } \\
\text { "sometimes the advertised products are interesting", } \\
\text { "sometimes the ad has a lot of valuable points, it's art and } \\
\text { can be just cool to watch" }\end{array}$ \\
\hline & $\begin{array}{l}\text { Getting to know the } \\
\text { product }\end{array}$ & 3 & $\begin{array}{l}\text { "to get to know the product", "to get to know new } \\
\text { products, interesting events or movies" }\end{array}$ \\
\hline & Other & 0 & - \\
\hline \multirow{7}{*}{ II } & No answer & 0 & - \\
\hline & Not watching & 1 & "I don't watch commercials" \\
\hline & I don't know & 0 & - \\
\hline & No choice & 16 & $\begin{array}{l}\text { "It can't be helped", "they show up where you can't skip } \\
\text { them - like in the cinema or on the Internet", "often I'm } \\
\text { forced to watch them while waiting for my movie TV } \\
\text { series, etc., "cause I have to", "I'm forced to watch them } \\
\text { during the breaks of some important things that I watch", } \\
\text { "because they pop-up and sometimes you can't turn } \\
\text { them off" }\end{array}$ \\
\hline & Self-chosen & 2 & $\begin{array}{l}\text { "for entertainment, sometimes to find out something } \\
\text { new", "sometimes for aesthetical values" }\end{array}$ \\
\hline & $\begin{array}{l}\text { Getting to know the } \\
\text { product }\end{array}$ & 1 & "to check what's new on the market" \\
\hline & Other & 0 & - \\
\hline
\end{tabular}




\begin{tabular}{|c|c|c|c|}
\hline \multirow{7}{*}{ III } & No answer & 1 & - \\
\hline & Not watching & 1 & "I don't watch commercials" \\
\hline & I don't know & 1 & "I don't know" \\
\hline & No choice & 11 & $\begin{array}{l}\text { "sometimes I have no other choice", "they're before the } \\
\text { materials that interest me", "I have no other choice", } \\
\text { "cause I have to", "they pop-up when I watch something } \\
\text { on YouTube or on the TV", "they're on the TV" }\end{array}$ \\
\hline & Self-chosen & 3 & $\begin{array}{c}\text { "they're dynamic with some lively music", "I'm searching } \\
\text { for bargains", "they introduce us to products and tell } \\
\text { interesting stories" }\end{array}$ \\
\hline & $\begin{array}{l}\text { Getting to know the } \\
\text { product }\end{array}$ & 1 & "to find out about new products" \\
\hline & Other & 2 & $\begin{array}{c}\text { "I try to skip them", "I try not to watch them, if I can } \\
\text { help it" }\end{array}$ \\
\hline
\end{tabular}

Source: Authors.

The analysis shows that two subjects did not give any answer to this question. Another four admitted to skipping commercials. One person could not find any reason ("I don't know") for watching them. Another 53 responses were grouped into a few themes: "no choice", "self-chosen", "getting to know the product", "other". The majority of subjects (35) offered an answer that can be seen as a lack of choice on their part ("no choice"). They pointed out that watching commercials is an inevitable part of functioning in the world run by media. They are an interruption in watching other, more valuable broadcasts; they are played on TV or they pop up on the internet. Nevertheless, they are inserted forcefully into the subject's media consumption. It is worth mentioning that in one of our previous questions, 38 people admitted that they feel they are being forced to watch commercials. One other finding worth mentioning shows that 11 people watch commercials out of their own free will, while admiring the entertaining and aesthetical values of advertisements. Five people had also pointed out the informative function of TV spots, which is represented by introducing them to new products.

H3: The first and second tier of our subjects will mainly point out the persuasive role of commercials (secondly the informational and reminding ones). The respondents from the third tier will be keener on choosing the entertaining and aesthetic roles.

While forming the experiment, we believed that from the recipient's perspective, the persuasive role of commercials (encouraging the viewer to buy a specific product or service) will be the dominant answer. We believed that the informational and reminding roles were secondary to that. We thought that the materials used to conduct our experiment in the last group might upscale the result 
of entertaining and aesthetical roles, since the presented audiovisual broadcasts distinguish themselves from traditional ones - they are focused on presenting the story. Moreover, the product or brand is not displayed in them vividly. In effect these broadcasts might be seen as a short film - fulfilling emotional or aesthetical needs in the viewer. In the question regarding commercial roles, our subjects could check a few different options, which added up to 196 responses, presented fully in Figure 5.

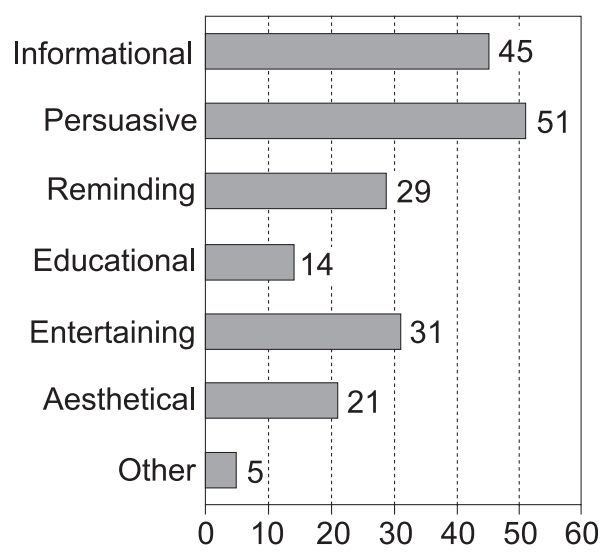

Figure 5. Roles of audiovisual commercials (responses: 196) (in numbers)

Source: Authors.

As predicted, the subjects had chosen the persuasive role of commercials with the highest frequency. The majority of recipients had also picked two other roles from standard typologies, that is, informational and reminding. Surprisingly, $53 \%$ of respondents pointed out that TV ads can be a source of entertainment, where $35 \%$ added to this response the aesthetical benefits of watching commercials. The least recorded answer was the educational role. Five people had chosen the "other" option, in which they added to the response field words such as "irritating" (Tier I), "persuasive", "manipulative" (Tier II), and "marketing” (Tier III). It is worth asking if any tendencies can be seen in the responses of certain tiers (Figure 6).

The hypothesis that we formed claimed that respondents from the third tier will be more prone to notice the entertaining and aesthetical role of commercials; however, this claim has been disproved by our research. The presented materials had no impact on subjects' responses, which (as in the other two tiers) predominantly focused on the persuasive and informational role of advertising. It is worth noticing that Tier III selected the lowest number of answers (with statistics from tiers being: I -73 , II -66 , III -57 ). Let us not forget that subjects from the third tier had to 


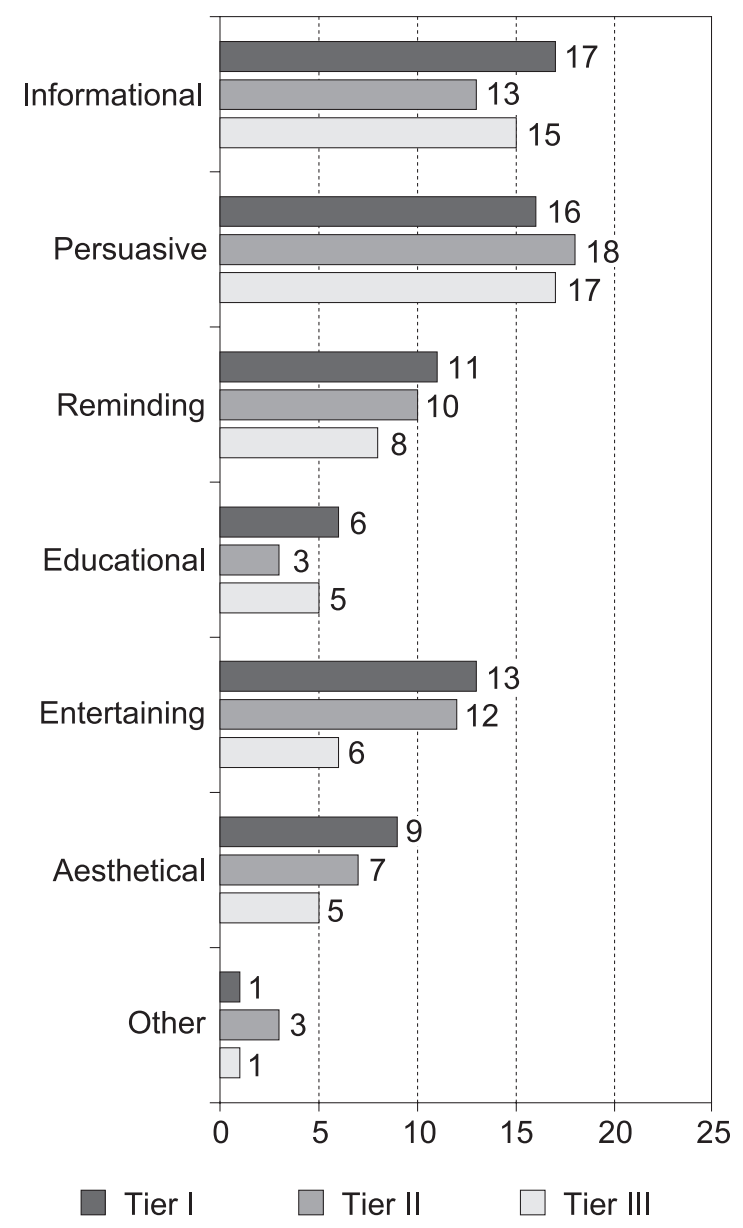

Figure 6. Roles of audiovisual commercials by tier (responses: 196) (in numbers)

Source: Authors.

watch more than 5 minutes of TV commercials. This might have resulted in a lack of enthusiasm for completing our questionnaire.

In the further parts of our experiment, we asked our subjects to organise six of the previously-mentioned roles of advertising from the most common (marked as 1) to the rarest (marked as 6). The results are presented in Table 4. 
Empirical research on the functions of audiovisual advertising

Table 4. The hierarchy of audiovisual roles of commercials

\begin{tabular}{|c|c|c|c|c|c|}
\hline Role & $\begin{array}{c}\text { Placement } \\
(1 \text { - most common, } \\
6 \text { - rarest })\end{array}$ & Tier I & Tier II & Tier III & $\begin{array}{c}\text { All } \\
\text { answers }\end{array}$ \\
\hline \multirow{6}{*}{ Informational } & 1 & 3 & 4 & 3 & 10 \\
\hline & 2 & 6 & 8 & 8 & 22 \\
\hline & 3 & 6 & 4 & 4 & 14 \\
\hline & 4 & 3 & 3 & 1 & 7 \\
\hline & 5 & 0 & 1 & 4 & 5 \\
\hline & 6 & 2 & 0 & 0 & 2 \\
\hline \multirow{6}{*}{ Persuasive } & 1 & 12 & 16 & 12 & 40 \\
\hline & 2 & 4 & 2 & 5 & 11 \\
\hline & 3 & 1 & 1 & 2 & 4 \\
\hline & 4 & 2 & 1 & 0 & 3 \\
\hline & 5 & 0 & 0 & 1 & 1 \\
\hline & 6 & 1 & 0 & 0 & 1 \\
\hline \multirow{6}{*}{ Reminding } & 1 & 1 & 0 & 2 & 3 \\
\hline & 2 & 7 & 7 & 2 & 16 \\
\hline & 3 & 5 & 5 & 8 & 18 \\
\hline & 4 & 4 & 4 & 4 & 12 \\
\hline & 5 & 1 & 4 & 1 & 6 \\
\hline & 6 & 2 & 0 & 3 & 5 \\
\hline \multirow{6}{*}{ Educational } & 1 & 0 & 0 & 0 & 0 \\
\hline & 2 & 0 & 0 & 1 & 1 \\
\hline & 3 & 2 & 1 & 3 & 6 \\
\hline & 4 & 6 & 3 & 1 & 10 \\
\hline & 5 & 5 & 2 & 4 & 11 \\
\hline & 6 & 7 & 14 & 11 & 32 \\
\hline
\end{tabular}


Agnieszka Barczyk-Sitkowska, Mateusz Krzekotowski

\begin{tabular}{|c|c|c|c|c|c|}
\hline \multirow{5}{*}{ Entertaining } & 1 & 3 & 0 & 2 & 5 \\
\cline { 2 - 6 } & 2 & 2 & 3 & 2 & 7 \\
\cline { 2 - 6 } & 3 & 4 & 6 & 3 & 13 \\
\cline { 2 - 6 } & 4 & 4 & 5 & 10 & 19 \\
\cline { 2 - 6 } & 5 & 5 & 4 & 1 & 10 \\
\hline \multirow{5}{*}{ Aesthetical } & 6 & 2 & 2 & 2 & 6 \\
\cline { 2 - 6 } & 1 & 0 & 0 & 1 & 1 \\
\cline { 2 - 6 } & 2 & 1 & 0 & 2 & 3 \\
\cline { 2 - 6 } & 3 & 3 & 3 & 0 & 6 \\
\cline { 2 - 6 } & 4 & 8 & 9 & 9 & 26 \\
\cline { 2 - 6 } & 6 & 6 & 4 & 4 & 14 \\
\hline
\end{tabular}

Source: Authors.

The analysis of gathered data shows a detailed description of answers from all tiers of respondents. According to our research, it is possible to organise the roles of advertising in order (from the most frequent selection to the least): persuasive, informative, entertaining, reminding, aesthetical and educational. Figures 7 and 8 answer the question regarding aesthetical and educational roles of commercials.

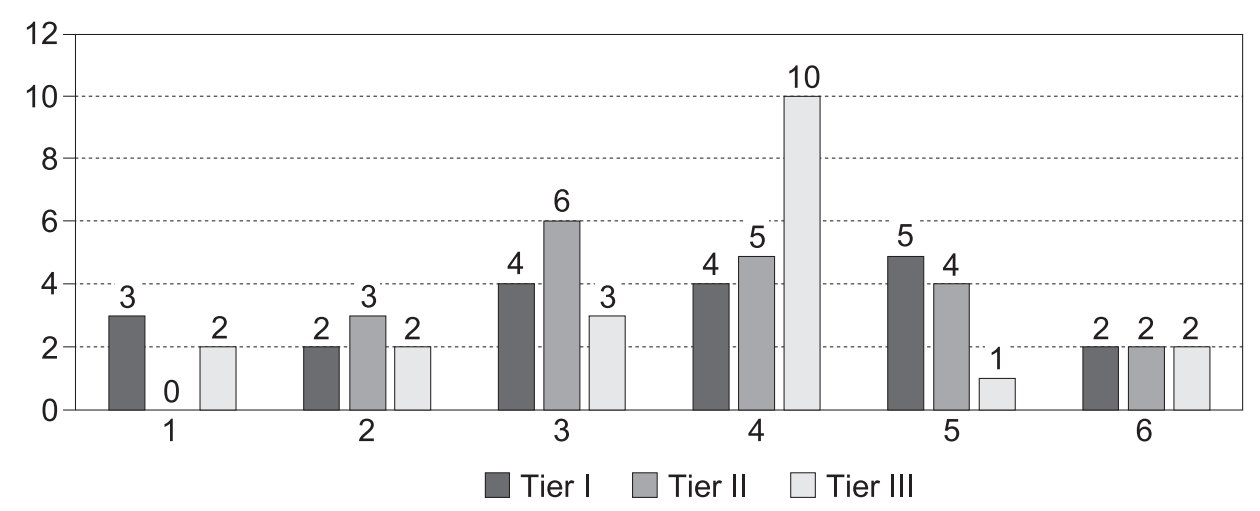

Figure 7. Entertaining role of commercials (in numbers)

Source: Authors.

The analysis of the data confirms the results gathered in the previous question. TV spots shown during the experiment had no impact on our result. The subjects, who are by default exposed each and every day to commercials, perceive this type 


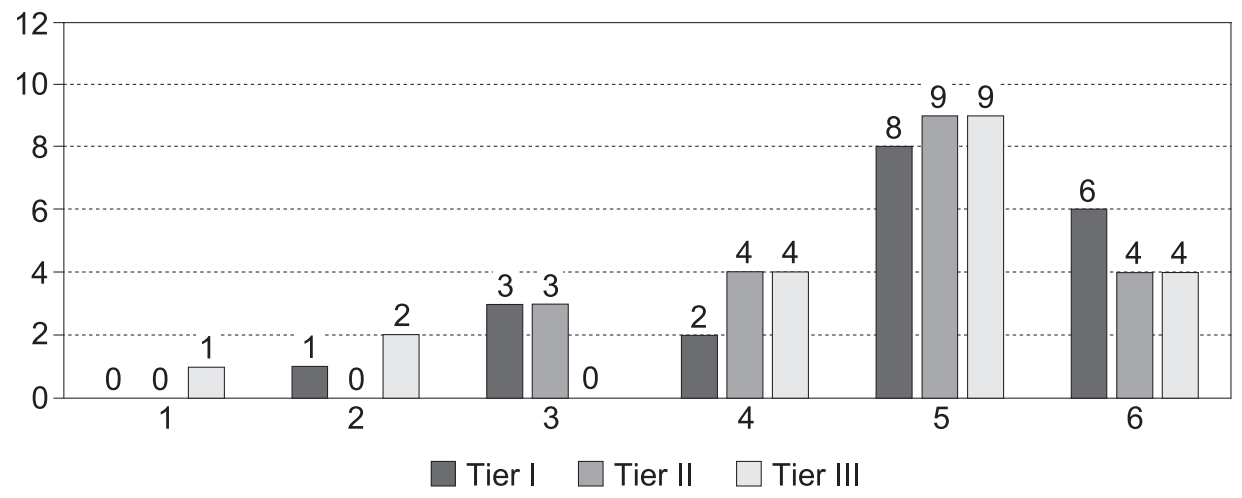

Figure 8. Aesthetical role of commercials (in numbers)

Source: Authors.

of broadcast as focused on acquainting the viewers with new products; convincing them to buy products, entertain, remind and/or build attachment in consumers. An exposure to three seemingly different commercials was not as powerful a stimulus to affect the perception of advertising communication on TV.

H4: The notion of having a favourite commercial will be more frequent in the respondents from the third tier.

In the last part of our research, we asked our participants about their favourite commercials. $80 \%$ of them admitted to having a TV advertisement that they truly like.

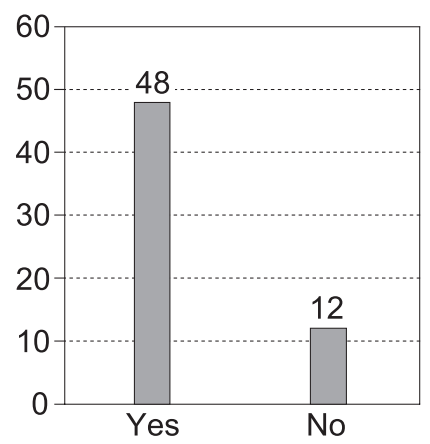

Figure 9. Are there any commercials you like? (Responses: 60) (in numbers)

Source: Authors.

As seen in Figure 10, contrary to our belief, the advertisements screened during the experiment had no impact on participants while answering this question.

What we can see in the responses to our last question seems interesting. Based on the responses, we were able to create a catalogue of favourite commercials of 


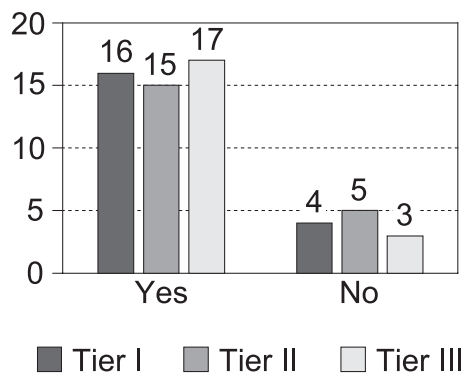

Figure 10. Are there any commercials you like? (By tier, in numbers)

Source: Authors.

our subjects. Similar to the question regarding their reasoning behind watching TV commercials, here we have also used a few themes which allowed us to organise the gathered responses (Table 5).

Table 5. The catalogue of subjects' favourite commercials

\begin{tabular}{|c|c|}
\hline Tier & Examples \\
\hline I & $\begin{array}{l}\text { Categories: "beer", "expensive cosmetics [...], cars, posing as short movies", "car } \\
\text { commercials". } \\
\text { Brands: Play (Polish mobile network), John Lewis, Orange Warsaw Festival, Lexus RC, } \\
\text { Kenzo, Coca-Cola ( } 2 \text { people), Jacobs. } \\
\text { Examples: "Pepsi - greatest soccer stars", "Żubr (Polish beer) - animated animals", } \\
\text { "Allegro - Christmas", "Flora by Gucci", "ANA Airlines by Tofu Media". }\end{array}$ \\
\hline II & $\begin{array}{l}\text { No response: } 2 \text { people. } \\
\text { Categories: "books, cultural or social events" - the subject claimed he had never } \\
\text { seen an example of this sort. } \\
\text { Brands: Allegro (Polish auction service) ( } 5 \text { people), Coca-Cola, SEAT Ibiza, Plush } \\
\text { (Polish mobile network mascot), IKEA, Lisner, Chanel Egoiste. } \\
\text { Examples: "Be like Turkish Airlines". }\end{array}$ \\
\hline III & $\begin{array}{l}\text { No response: } 1 \text { person. } \\
\text { Categories: "There's few of them — though I can't point them out, but these are } \\
\text { commercials connected to social and human integration problems". } \\
\text { Brands: Allegro ( } 9 \text { people), Nissan, Mercedes, PKO BP (Polish bank). } \\
\text { Examples: "Katarzyna Skrzynecka (Polish celebrity) dancing with pate", "IKEA by } \\
\text { Darwin Film Group", "Morliny weiner, new campaign by Reserved, Christmas ads } \\
\text { by Allegro, Olympic ads about mothers (by P\&G)". }\end{array}$ \\
\hline
\end{tabular}

Source: Authors.

The analysis of data shows that even though the commercials presented during the experiment did not affect prominently the view on the role of audiovisual advertising, they could affect the subject's response about their favourite commercial example. It is worth noticing that as many as 9 people from the last tier pointed out the 
commercial of the auction service website Allegro, which was part of the examples presented by us during the experiment. Also mentioned was the main character from the Polish Bank TV spot (National Bank of Poland: Making Key Decisions).

\section{FINAL NOTES}

As shown in the previously-mentioned CBOS report from 2011, Polish people felt more hostile towards TV commercials over time (Table 6).

Table 6. Attitudes towards commercials in Poland

\begin{tabular}{|l|c|c|c|}
\hline \multirow{2}{*}{ Overall, what's your attitude towards commercials? } & \multicolumn{3}{|c|}{$\begin{array}{c}\text { Responses in years } \\
\text { (percent) }\end{array}$} \\
\cline { 2 - 4 } & 1999 & 2005 & 2011 \\
\hline $\begin{array}{l}\text { I don't like commercials, I don't watch them, } \\
\text { I don't listen to them }\end{array}$ & 28 & 34 & 38 \\
\hline $\begin{array}{l}\text { I don't like them, yet I'm forced to (watch them, } \\
\text { listen to them) }\end{array}$ & 47 & 44 & 48 \\
\hline Overall, I like commercials & 20 & 17 & 13 \\
\hline It's hard to state my attitude towards commercials & 5 & 5 & 1 \\
\hline
\end{tabular}

Source: CBOS, February 2011, p. 2.

Unfortunately, the most recent research published on the subject was gathered 8 years ago. It might be the main reason why its results differ from the ones gathered by us. In our research only $22 \%$ of subjects admitted to having a negative attitude towards TV commercials. More interestingly, this indicator was the lowest in the group watching advertainment examples. It is worth noting that the probe of the experiment came from Journalism and Social Communication students. Partially these students are interested in gaining an advertising major, which will become a part of their future livelihood. This may also result in a more positive attitude towards commercials. At the same time, the majority of the participants (63\%) felt forced to watch omnipresent TV advertisements, which they cannot run away from.

The most important purpose of our research was devoted to pointing out the roles of audiovisual advertising. The analysis of our data partially confirmed our predictions - popular answers were the three fundamental commercial roles mentioned by, for example, Kozłowska (informational, persuasive and reminding) (2001). We must note that the entertaining role preceded the reminding one it was chosen by $52 \%$ of our respondents. As many as $35 \%$ of subjects had also chosen the aesthetical role. This justifies the necessity of widening the traditional catalogue of advertising roles pointed out by Michalik in his article dedicated to the 
entertaining role of commercial broadcasts (2007). Apart from entertaining, the aesthetical role seems to be important.

The examples shown during our experiment did not alter sufficiently the role of advertising in our subjects. Contrary to our belief, the third tier of our respondents did not point out the entertaining or aesthetical roles of commercials more often than the respondents from other tiers. Based on this observation, we can presume that presenting commercials will not permanently change attitudes towards commercials in viewers, however it might build up the catalogue of commercials that the viewer likes. An example of this process is the mention of Allegro advertisements by subjects, that have been presented as a part of our experiment before completing the questionnaire. These results allow us to think that the examples presented in case studies during classes can in some way alter students' opinions.

It seems that changing the overall attitude towards commercials in the modern viewer is impossible. By "attitude" we mean an outlook that commercials serve as a form of persuasion to buy "something". The overwhelming presence of advertisements, their repetitiveness and overuse of the same schemes are to blame for such a perception. On the other hand, some commercials can awaken a positive attitude in the viewer and even be mentioned as the viewer's favourite, which as a result makes the advertisement stronger than its direct competition. This chance, we believe, lays in the fusion of advertising and entertainment. To quote Michalik: "In times of fierce competition between brands, products are becoming more similar to each other and a growing negative response to commercials by consumers, the entertaining value of the broadcast is the key factor that makes the viewer want to get familiar with its content and therefore improves its [commercial's] effectiveness" (Michalik, 2007 , p. 16). Examples of such commercials we try to convey in our work.

\section{REFERENCES}

Aronson, E., Wilson, T. D., \& Akert, R. M. (1997). Psychologia społeczna. Serce i umyst [Social psychology. The heart and the mind]. Poznań: Zysk i S-ka.

CBOS (luty, 2011). Nudza, drażniq, dezinformuja - Polacy o reklamach [They bore, they irritate, they misinform - Polish attitudes towards commercials]. Warszawa.

Eco, U. (1996). Nieobecna struktura [The absent structure]. Transl. A. Weinsberg, P. Bravo. Warszawa: KR.

Goban-Klas, T. (2004). Media i komunikowanie masowe. Teorie i analizy prasy, radia, telewizji $i$ Internetu [Media and mass communication. Theories for analysing press, radio, TV and internet]. Warszawa: PWN.

Golka, M. (1994). Świat reklamy [The world of advertising]. Puszczykowo: Agencja Badawczo-Promocyjna ARTIA.

Grzegorczyk, A. (2010). Reklama [Advertising]. Warszawa: Polskie Wydawnictwo Ekonomiczne.

Kozłowska, A. (2001). Reklama: socjotechnika oddziaływania [Advertising: Social techniques of influence]. Warszawa: Szkoła Główna Handlowa.

Michalik, R. (2007). Rozrywkowa reklama z marką [Advertainment with brands]. Marketing w Praktyce, 2, pp. 14-17. 
National Bank of Poland, Making Key Decisions. Retrieved February 9, 2019 from https://www.youtube.com/watch?v=-Jb-1LgCY1M.

Olszanecka-Marmola, A. (2016). Metoda eksperymentalna w procesie badania mediów [Experimental methods in researching the media]. Zeszyty Naukowe Towarzystwa Doktorantów UJ. Nauki Społeczne, 2(13), pp. 103-117.

Oniszczuk, Z. (1988). Pojęcie funkcji w badaniach nad społecznym oddziaływaniem prasy [Defining function in research on the social impact of press]. Zeszyty Prasoznawcze, 2(116), pp. 41-52.

Russell, C. A. (2007). Advertainment: Fusing Advertising and Entertainment. Michigan: University of Michigan, Yaffe Center.

Wszołek, M. (2016). Reklama - perspektywa empiryczna [Advertising: An empirical perspective]. Wrocław: Libron. 